\title{
The Effect of Firm's Age, Size and Growth on Its Profitability: Evidence from Jordan
}

\author{
Musa Abdel Latif Ibrahim Al Nawaiseh \\ Department of Accounting, Business College, The University of Jordan-Jordan, Aqaba
}

\begin{abstract}
This study aims at testing the effect firm's age, size and growth on its profitability based on the financial data of (22) Jordanian insurance firms that are registered in the Amman Security Exchange (ASE) during the period (2008-2017). They represent $95.2 \%$ of insurance firms. The study relied on secondary data of insurance firms that have been published on their website and on ASE website In the study, the mean, standard deviations were used to describe the characteristics of the variables. Simple regression analysis was used to test the study's hypotheses. Simple. the skewness test of all variable is used to know if they have a normal distribution. The study shows that there is an insignificant effect of the insurance firm's age, size, and growth on its profitability. It recommends financial managers to analyze the relationship between a firm's age, size, growth, and profitability before making any decision in the fields of expanding business, renewing assets, manufacturing high-quality products and appointing new employers. In a recession period, managers should not adopt a strategy to achieve high growth in the short run, they should also reduce the size of the firm's operations. These procedures are important for these firms to maintain a balance between growth and profitability.
\end{abstract}

Keywords: Firm's Age, Firm's Size, Firm's Growth, and firm's Profitability.

DOI: $10.7176 / \mathrm{EJBM} / 12-5-10$

Publication date: February $29^{\text {th }} 2020$

\section{Introduction}

The firm's size is an important factor in determining its success in obtaining finance in addition to access in large economic production. The finance decision is usually based on studying and analyzing profitability as a measure of its performance. The firm's size represents the quantity and variety of its products, or services and its ability to provide them to customers, according to the concept of large scale production. This involves production at lower costs and thus maximizing profits.

The firm's management often aims to maximize profit in the long run. This agrees with the organization theory. If it does all efforts to achieve the maximum level of growth, it will achieve the maximum level of profitability. From a managerial perspective, the firm's growth depends on its size. Profitability measures the entity's performance, management efficiency in using assets in increasing the owners' fortune and its success in achieving its activities. Because of the importance of profitability proxy, many studies were conducted to identify the factors affecting it. The firm's age represents the length of the period from its establishment as a physical and legal entity. There is no agreement between researches on the effect of firm's age, size, and growth on its profitability. In Jordan there is little studies that tests the relationship between these variables. Therefore, this study aims to provide some effort in this field, and to test the effect of the firm's age, size, and growth of assets on its profitability. The following parts of the study investigates the study's objective, Problem, Hypotheses, literature review, methodology (population and Study's Sample, data, variables, analytical Model, statistical tools, hypotheses test), discussion the results, recommendations, and references.

\section{The objective of the study}

The study aims to examine the effect of the Jordanian insurance firm's age, size and growth on their profitability.

\section{The problem of the study}

The problem of this study came from the importance of interpretation of the relationships between the variable of the study to all users of the financial reports, especially since the researcher did not find more studies in this field especially in the insurance sector in Jordan.

\section{The Hypotheses of the study}

After surveying the previous researches and in light of the study's objective, researcher developed the following hypotheses:

H01: There is no statistically significant effect of the firm's age on its profitability.

H02: There is no statistically significant effect of the insurance firm's size on its profitability.

H03: There is no statistically significant effect of the insurance firm's assets growth on its profitability. 


\section{Literature review}

\subsection{The relationship between the firm's size and its profitability}

Many studies tested the relationship between the firm's size and its profitability. The firm's size affect its performance (Serrasqueiro et al., 2008, Berger and Bonaccorsi ,2006) large firms have a better performance , they can use new ways to face market risks and uncertainties, they have better opportunities to avoid losses, and greater achievements (Onder, 2003), they have the ability to negotiate suppliers and competitors, acquire new technology, train employees to make them extensive professional experience, and gains control on the market. Gschwandtner (2005) found that the firms' profits bases on concentration in the industry, so they achieve higher profit rates in the long run. According to Vijayakumar and Tamizhselvan (2010) the relationship between the firm's size and its profitability is positive depending on a sample of 15 Indian enterprises. Lee (2009) found that firm's size played a significant role in interpreting their profitability depending on data of 7,000 US firms. Ozgulbas et al., (2006) found that the performance of the large firms is better depending on the data of Turkish firms that are registered in the financial market of Istanbul during the period 2000-2005. Velnampy and Nimalathasan (2010) found that the relationship between the firms' size and their profitability is positive depending on the data of Ceylon and the commercial banks in SriLanka during the period 1997-2006, and he found that there is no relationship between the two variables in Silan banks. In his study, Mule et al., (2015) found a positive relationship between the firms' size and its profitability based on Kenyan firms that were registered in the financial market of Nairobi during the period 2010-2014. The studies of Papatogonas (2007), Abiodun (2013) and Ilaboya et al. (2016) appear to have a significant effect of firm's size on its profitability. Whereas the studies of Goddard et al. (2005), Amato and Burson (2007), Becker-Blease et al., (2010) show a weak and negative relationship between the firm's size and its profitability, but Niresh and Velnampy (2014) found in his study insignificant relationship between the two variables.

\subsection{The relationship between the firm's growth and its profitability}

One of the most important objectives of the firm's management is to achieve high profit by achieving high growth and increasing the firm's size. Achieving a high growth rate is one of the indicators of a firm's success that is affected by its profitability. The firm's growth is a continuous process that is renewed and influenced by its profitability (Vijayakumar and Tamizhselvan, 2010). Malik (2011) argues that firm's growth increases by reinvesting undistributed profits. Firm's growth is a gradual process, starting by increasing sales or the expansion of the business, such as in acquiring new investments in subsidiaries or associates, developing and increasing the number of employees. The profitability and growth variables usually work in the same trend (Geroski and Mazzucato, 2002). There is no evidence insuring a constant relationship between profitability and growth that can be generalized (Coad, 2007). Jang and Park (2011) argue that profitable firms can keep part of their profits to use them in capturing the growth opportunities, and making additional profits. Yoo and Kim (2015) found in their study that profit management strategy limits the firm's growth, the high growth of the firm in the previous fiscal period boosts profitability, also the increasing returns during the growth period improves productivity and profitability, a strategy of achieving high growth in the short term will make management less flexible, less able to achieve satisfactory growth during the recession, and reduces the size of the firm's operations. The sudy of Mukhopadhyay and AmirKhalkhali (2010) shows that the large firms grow at a faster rate. Glancey (1998) found in his study a strong relationship between firm's profitability and growth. Markman and Gartner (2002) and Fitzsimmons et al. (2005) found insignificant relationship between the firm's growth and its profitability. Wagenvoort (2003) study showed that small-scale firms will face financial pressures, this will hinder their growth. Bottazzi et al. (2001) found a positive and statistically significant impact of operating income on the firm's growth. Guariglia (2009), found that firms with high profit rates have high investment rates. Coad (2007) found that there is no relationship between profitability and growth in his study. Serrasqueiro (2008), Cox et al. (2002) found a positive relationship between firm's profit and its sales growth. Nakano and Kim (2011) found that the current profits are required for future growth, while the current excessive growth has a negative impact on future profits and a negative relationship between the firm profitability and its growth. Delmer et al., (2003) believes that growth patterns vary over time; It is difficult to predict average growth. Cooley and Quadrini (2001) found that the firm's growth decreases over years.

\subsection{The relationship between the firm's age and its profitability}

By the passage of year after establishment, firm become experience in operation, meeting challenges, and exercising the social responsibility after the passage of year (Pollet, 2009). The firm's age plays an important role as one of the determinants of the firm's performance. New firms are more profitable and growth than large ones, because they can create new jobs, achieve local growth, innovate new work procedures and train their employees, but Long-lived firms that have pooled resources, extensive experience, a better reputation in the marketplace, and large quantity of information can overcome difficulties and work efficiently. The firm's age plays an important role as one of the determinants of the firm's performance (Curran et al., 1993). In recent days researchers interest 
in testing the relationship between firm's age and its profitability. Some of them found a positive relationship between the firm's age and its profitability such in the studies of Papatogonas (2007), but Dogan (2013) found a negative relationship between the two variables firm's age. Ammar et al. (2003) examined the relationship between the age and firm's performance, and found that the age of the firm improves its performance.

There is no agreement between researchers on the effect of the firm's age, size and growth on profitability. This gap appears in the Jordanian studies. Therefore, this study came to cover this gap in one of the developing countries. This study will examine the impact of the firm age, size, and growth on its profitability.

This study will discuss the variables and the statistical methods, data collection, analysis, and discuss the results and presentation, and to reach conclusions and recommendations.

\section{The study methodology}

The methodology consists of the study's population and sample, the variables, the statistical techniques, the hypotheses test, and the results discussion.

\subsection{The study population and sample}

The study sample consists of 22 firms. They represent $95.2 \%$ of insurance firms that are registered on ASE. The study depends on the financial reports of these firms within the period (2008-2017). Table No. (1) summarizes the number of the sample firms, and the observations' per firm on its financial statements and the total observations.

Table 1 Sample Firms and the Observations on their Reports

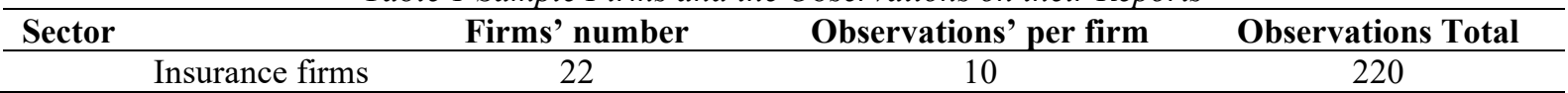

\subsection{Data collection}

The study relied on a secondary data of insurance firms that has been published on their website in addition to the financial statements published on the ASE website.

\subsection{The study variables}

The study examines the effect of firm's age; size and Growth (independent variable) on its profitability (dependent variable). See Table 2 appears the variables, their symbol and the measuring variable method.

Table 2 Measuring Variables

\begin{tabular}{lccc}
\hline Variable & symbol & \multicolumn{1}{c}{ Variable measuring } & Source \\
\hline Profitability & ROE & ROE $=$ Net profit $\div$ Equity & Odongo et al., 2014. \\
Firm's Age & Age & Log (the number of years since listing) & Mule et al., 2015. \\
Firm' Size & Size & Log total assets & Pandy, 2004. \\
Firm's Growth & AG & Assets Growth= $\left(\mathrm{TA}_{\mathrm{t}}-\mathrm{TA}_{\mathrm{t}-1}\right) \div \mathrm{TA}$ & $\mathrm{t}-1$ \\
\hline
\end{tabular}

\subsection{Analytical Model}

The analytical model of took the form;

$$
\text { ROA }=\beta_{0}+\beta_{1} \text { Age }+\beta_{2} \text { Size }+\beta_{3} \text { Growth }+\dot{\varepsilon}
$$

Where; ROE: Return on Equity, $\mathrm{B}_{0}$ : Constant, Size: log Total assets, Age: log of the number of years since firm s' inception as the proxy variable for age, Growth: Annual growth rate of the total assets, and $\dot{\varepsilon}$ - Random error.

\subsection{Statistical methods}

In the study the mean, standard deviations were used to describe the variables characteristics. Simple regression analysis was used to test the study's hypotheses.

According to the descriptive statistics which was contained in Table No.3, the Standard deviations in the variables data of all companies were low, the biggest figure was associated with the log revenue (sales) and the lesser one was associated with variable ROE.

Table 3 Descriptive statistics

\begin{tabular}{lcccc}
\hline Variable & Observations No. & mean & Std. Deviation & Skewness \\
\hline ROE & 220 & 0.017 & 0.091 & -1.778 \\
Log Age & 220 & 1.480 & 0.242 & 0.875 \\
Log Assets & 220 & 7.352 & 0.252 & -1.004 \\
AG & 220 & 0.050 & 0.106 & -1.105 \\
\hline
\end{tabular}

To test the normal distribution of the study's variables, the skewness rate to standard error technique is used. Table No.3 appears that the skewness rate of all variables between $(-2,2)$, this means that each of these variables had a normal distribution.

To test the relationship between study's variables, correlation technique is used as in table 4 . The largest 
correlation is between ROE and AG, and the lesser one is between ROE and Log age.

Table 4 Correlation Metrics

\begin{tabular}{lccc}
\hline & Log Age & Log Assets & AG \\
\hline ROE Pearson Correlation & $-0.197^{*}$ & 0.000 & $0.618^{* *}$ \\
Sig.(2-tailed) & 0.000 & 0.043 & 0.002 \\
N & 220 & 220 & 220 \\
\hline
\end{tabular}

** Correlation is significant at the 0.00 level (2- tailed)

* Correlation is significant at the 0.05 level (2- tailed).

6.6 Hypotheses test

H01: There is no statistically significant effect of the insurance firm's age on its profitability.

Table 5 Regression coefficients of the impact of Log age on ROE

\begin{tabular}{lcccc}
\hline Model & Coefficient & Std. Error & t-Statistic & Prob. \\
\hline Constant & 0.127 & 0.124 & 1.027 & 0.317 \\
Age (log Age) & -0.074 & 0.083 & -0.808 & 0.380 \\
R-squared & 0.039 & & & \\
Adjusted R-squared & 0.009 & & & \\
F-statistic & 0.807 & & & \\
Prob. (F-statistic) & 0.380 & & & \\
\hline
\end{tabular}

a. Predictor (constant), (Age) Log Age

b. Dependent Variable: (ROE) EAT/Equity

Table 5 shows the analysis of the relationship between firm's age and its profitability. Beta coefficient is 0.074. Moreover, the adjusted R-square is $0.9 \%$, this means that a $0.9 \%$ of the total deviations in profitability variable can be interpreted by the linear relationship in the model. As a result, there is no statistically significant effect of firm's age on its profitability at p-value less than 1\%. Hypothesis $\mathrm{H}_{01}$ should be accepted.

$\mathbf{H}_{02}$ : There is no statistically significant effect of the insurance firm's size on its profitability. Table 6 The regression coefficients of the effect of Log Assets on ROE

\begin{tabular}{|c|c|c|c|c|}
\hline Model & Coefficient & Std. Error & t-Statistic & Prob. \\
\hline Constant & -1.144 & 0.538 & -2.126 & 0.046 \\
\hline Log Assets Size & 0.158 & 0.073 & 2.160 & 0.043 \\
\hline $\begin{array}{l}\text { R-squared } \\
\text { Adjusted R-squared } \\
\text { F-statistic } \\
\text { Prob.(F-statistic) }\end{array}$ & $\begin{array}{l}0.189 \\
0.149 \\
4.665 \\
0.043\end{array}$ & & & \\
\hline
\end{tabular}

a. Predictor (constant), (Size) log Assets

b. Dependent Variable: (ROE) BAT/Equity.

Table 6 shows the analysis of the relationship between size (log assets) and profitability (ROE). Beta coefficient is 0.158 . Moreover, the adjusted R-square is $14.9 \%$, this means that a $14.9 \%$ of the total deviations in profitability variable can be interpreted by the linear relationship in the model. As a result, there is statistically significant effect of firm's size on profitability at p-value less than $5 \%$. Hypothesis $\mathrm{H}_{02}$ should be rejected.

$\mathrm{H}_{03}$ : There is no statistically significant effect of the insurance firm's assets growth on its profitability. Table 7 The regression coefficients of the effect of Assets Growth on ROE

\begin{tabular}{|c|c|c|c|c|}
\hline Model & Coefficient & Std. Error & t-Statistic & Prob. \\
\hline Constant & -0.039 & 0.015 & -2.563 & 0.019 \\
\hline $\mathrm{AG}$ & 1.063 & 0.178 & 5.961 & 0.000 \\
\hline R-squared & 0.640 & & & \\
\hline Adjusted R-squared & 0.622 & & & \\
\hline F-statistic & 35.528 & & & \\
\hline Prob.(F-statistic) & 0.000 & & & \\
\hline
\end{tabular}

a. Predictor (constant), (AG) Assets growth

b. Dependent Variable: (ROE) BAT/Equity

Table 7 appears the analysis of the relationship between assets growth and profitability. Beta coefficient is 1.063. Moreover, the adjusted R-square is $62.2 \%$, this means that a $62.2 \%$ of the total deviations in profitability variable can be interpreted by the linear relationship in the model. As a result, there is a statistically significant effect of Assets growth on profitability at p-value less than 1\%. Hypothesis $\mathrm{H}_{02}$ should be rejected. 


\section{Conclusions}

From testing hypotheses, and investigating preceding studies, there are three conclusions can be drawn: The first one is; there is no statistically significant effect of the insurance firm's age on its profitability, This result consistent with the studies' results of Papatogonas (2007) and found positive significant relationship between firm's age and profitability. The second conclusion is; there is a statistically significant effect of the insurance firm's size on its profitability, this result consistent with studies' results of The studies of Ilaboya et al. (2016), Abiodun (2013), and doesn't consistent with the studies' results of Becker-Blease et al., (2010)Goddard et al. (2005), Amato and Burson (2007), Niresh and Velnampy (2014), and Vijayakumar \& Tamizhselvan (2010). The third conclusion is; there is statistically significant effect of the insurance firm's growth on its profitability, this result consistent with the studies' results of Coban (2014), Serrasqueiro (2008), Cox et al., (2002), and Glancey (1998) and disagree with the results of studies of Markman and Gartner (2002), Nakano and D.Kim (2011) and Coad (2007).

\section{Recommendations}

The study recommends financial managers in these firms analyze the relationships between firm's age, size and growth, and profitability before taking any decision in the field of firm's expanding, innovation of its assets, producing new products and employing new employers. They also maintain a balance between firm's growth and its profitability. In recession period managers should not adopt a strategy to achieve high growth in the short term because it will make management less flexible and less able to achieve satisfactory growth during it. They should reduce the size of the firm's operations. It is important for these firms to maintain a balance between growth and profitability

\section{References}

Abiodun, Babalola, Yisau. (2013). The Effect of Firm Size on Firms Profitability in Nigeria, Journal of Economics and Sustainable Development, 4(5); 90-94, www.iiste.org ISSN 2222-1700 (Paper).

Amato, L. H., \& Burson, T. E. (2007). The Effects of firm size on profit rates in the financial services. Journal of Economics and Economic Education Research, 8(1), 67-81.

Ammar, Abdurahman, Awad S. Hanna, Eric V. Nordheim, and Jeffrey S. Russell. (2003). Indicators variables model of firm's size-profitability relationship of electrical Contractors using financial and economic data. Journal of Construction Engineering and Management 129 (March): 192-197.

Becker-Blease, J. R., Kaen, F. R, Eteban, A. \& Bauman, H. (2010). Employees, firm size and profitability in U.S manufacturing industries. Investment Management and Finance Innovation, 7(2), 7-23.

Berger, A.N., and Bonaccorsi di Patti, E. (2006). Capital structure and firm performance: A new approach to testing pecking order theory and an application to the banking industry. Journal of Banking and Finance, 30 (4), 1065-1102.

Bottazzi, G., Dosi, G., Lippi, M., Pammolli, F. and Riccaboni, M. (2001).Innovation and corporate growth in the evolution of the drug industry. International Journal of Industrial Organization, 19, 1161-1187.

Coad, A. (2007). Testing the principle of "growth of the fitter: the relationship between profits and firm growth. Structural Change and Economic Dynamics 18, 370-386.

Coban, Serap .(2014). The Interaction between Firm Growth and Profitability:Evidence from Turkish (Listed) Manufacturing Firms, Bilgi Ekonomisi ve Yönetimi Dergisi Cilt: IX Say1: II; 73- 82. The Journal of Knowledge Economy \& Knowledge Management / Volume: IX FALL

Cooley, T.F. \& Quadrini, V. (2001), Financial markets and firm dynamics. American Economic Review, 91: 12861310.

Cox, H.; Mowatt, S.; Prevezer, M., (2002).The Firm in the Information Age: Organizational Responses to Technological Change in the Processed Foods Sector, Industrial and Corporate Change, 11(1), 135-158.

Curran, J., Jarvis, R., Blackburn, R.A. \& Black, S. (1993), "Networks and small firms: constructs, methodological strategies and some findings", International Small Business, Journal, 11 (2): 13-24.

Delmar, F., Davidsson, P., and Gartner, W. B. (2003). Arriving at the high-growth firm. Journal of Business Venturing, 18(2), 189-216.

Dogan M .(2013). Does firm size affect the firm profitability? Evidence from Turkey', Research Journal of Finance and Accounting, V 4(4), pp. 53-59.

Fitzsimmons, J.R., Steffens, P.R., and Douglas E.J. (2005). Growth and Profitability in Small and Medium Sized Australian Firms. AGSE Entrepreneurship Exchange, Melbourne, February 2005.

Glancey, K. (1998).Determinants of growth and profitability in small entrepreneurial firms. International journal of Entrepreneurial Behavior and Research, 4(1), 18-27.

Goddard, J., Tavakoli, M. \& Wilson, J. (2005). Determinants of profitability in European Manufacturing and Service. Evidence from dynamic panel model. Applied Financial Economics, 15 (18): 1269-1282.

Gschwandtner, A. (2005). Profit Persistence in the 'Very Long Run: Evidence from Survivors and Exiters. Applied Economics,37,793-806. 
Guariglia, A. (2007). Internal Financial Constraints, External Financial Constraints, and Investment Choice: Evidence from A Panel of UK Firms. Journal of Banking and Finance, 32, 1795-1809.

Ilaboya, O. J., and Ohiokha, I. F.(2016). Firm Age, Size and Profitability Dynamics: A Test of Learning by Doing and Structural Inertia Hypotheses, Business and Management Research, 5(1); 29- 39, available at: http://bmr.sciedupress.com.

Jang, S., \& Park, K. (2011). Inter-relationship between firm growth and profitability. International Journal of Hospitality Management, 30, 1027-1035. http://dx.doi.org/10.1016/j.ijhm.2011.03.

Lee, J. (2009). Does size matter in firm performance? Evidence from U.S public firms. International Journal of Economics and Business, 16(2), 189-203. http://dx.doi.org/10.1080/13571510902917400.

Malik, H., (2011), Determinants of Insurance Companies Profitability: An Analysis of Insurance Sector Of Pakistan, Academic Research International, Vol. 1, Issue 3, ISSN: 2223-9553.

Markman, G.D. and Gartner, W.B. (2002). Is extraordinary growth profitable? A study of Inc 500 high-growth companies. Entrepreneurship Theory and Practice, 27, 65-76.

Mukhopadhyay, Arun and AmirKhalkhali, Sal .(2010).Profitability Performance And Firm Size-Growth Relationship, Journal of Business \& Economics Research, 8(9);121-125.

Mule, Robert Kisavi, Mukras, Mohamed Suleiman and Nzioka, Onesmus Mutunga .(2015). Corporation, Size, Profitability and Market Value: An Economic Panel Analysis of Listed firms, European Scientific Journal, 11(13); $376-396$.

Nakano, A. and D. Kim .(2011). Dynamics of growth and profitability: The case of Japanese manufacturing firms. Global Economic Review, 40(1): 67-81.

Niresh, J. Aloy and Velnampy, T.(2014). Firm Size and Profitability: A Study of Listed Manufacturing Firms in Sri Lanka, International Journal of Business and Management; 9 (4); 57-64.

Odongo, K., Mokoteli, T.M., \& Maina, L. (2014). Capital structure, profitability and firm value: Panel evidence of listed firms in Kenya. MPRA, 57116. Retrieved from http://mpra.ub.unimuenchen.de/57116.

Onder, Z. (2003), Ownership concentration and Firm Performance: Evidence from Turkish firms METU studies in development 30(2): 181-203.

Ozgulbas, N., Koyuncugil, A. S., \& Yilmaz, F. (2006). Identifying the effect of firm size on financial performance of SMEs. The Business Review, Cambridge, 6 (1), 162- 167.

Pandey , M. 2004. Capital structure, profitability and market structure: evidence from Malaysia. Asia Pacific Journal of Economics and Business, 8(2):78-89.

Papatogonas, E. M. (2007). Financial performance of large and small firms: Evidence from Greece. International Journal of Financial Service Management, 2(1), 14-20. http://dx.doi.org/10.1504/IJFSM.2007.011668.

Pollet, J. (2009). Proxy contests and the efficiency of shareholder oversight, Journal of Financial Economics, 20: 237-65.

Serrasqueiro, Z.S. and Nunes P.M., (2008). Performance and size: empirical evidence from Portuguese SMEs, Small Business Economics, 31:195 - 217.

Velnampy, T., \& Nimalathasan, B. (2010). Firm Size on Profitability: A comparative study of Bank of Ceylon and Commercial Bank of Ceylon Ltd in Sri Lanka. Global Journal of Management and Business Research, 10 (2), 96-100.

Vijayakumar, A., \& Tamizhselvan, P. (2010). Corporate Size and Profitability: An Empirical Analysis. College Sadhana-Journal for Bloomers of Research, 3(1), 44-53.

Wagenvoort R. (2003) Are finance constraints hindering the growth of SMEs in Europe?, EIB Paper, No. 7, Economic and Financial Studies, European Investment Bank. IX.

Yoo, Seungkyu and Kim, Jaejun. (2015). The Dynamic Relationship between Growth and Profitability under LongTerm Recession: The Case of Korean Construction Companies, Sustainability 7; 15982-15998, doi:10.3390/su71215796. 